\title{
Internet Addiction in Freshmen Engineering Students in India
}

\author{
Gayatri lyer* and Ramajanaki Doraiswamylyer $^{* *}$
}

\begin{abstract}
The purpose of this paper is to describe the process undertaken to evaluate the psychometric properties of a questionnaire developed to measure internet addiction in freshmen engineering students in India. A questionnaire survey was conducted using convenience sampling method, among 97 freshmen engineering students from four colleges in Mumbai, identified as over users by counsellors of their institutions. Factor analysis of the 16-item instrument yielded a threefactor structure with scale composite reliability above 0.7 for each of the factors and average variance extracted scores above 0.5. An Independent samples t-test also showed a significant difference in internet addiction by substance users $(M=31.34, S D=12.38)$ as compared to nonusers $(M=24.93, S D=12.06 ; p<0.05)$. Programmes that engage students in meditation, yoga and intense physical activities should be encouraged so that students learn to encounter face to face interactions with real humans rather than the surreal ones behind their screens. It is also essential that parents, teachers and other authorities recognize changing behaviors among students and create an environment of congeniality where the individual can share his or her feelings openly.
\end{abstract}

Keywords: Adolescent, Engineering, Factor analysis, Freshmen, Internet Addiction, Validity

\section{INTRODUCTION}

The evolution of information technology has revolutionized the way we perceive the world and process information. Around $50 \%$ of internet users in the world belong to Asia and, in Asia , India holds a $25.4 \%$ share in the internet usage statistics. There has been a $111 \%$ increase in the usage of internet in India in a decade from 2000 to 2019. Internet has become quintessential for effective and efficient working of personal and professional lives and is seen by users as a panacea for most problems be it medical, academic or fun. The problematic issue as far as internet usage is concerned is the difficulty in discerning whether the internet use is actually a real use or an overuse. It was in the 1990s that the term 'technological addiction' came to be used in psychological literature which described the situation of a "non-chemical addiction that involved human-machine interaction". (Griffiths, 1999; Shaw \&, 2008). Adolescence is a very crucial period where an individual experiences dynamic biological, psychological and behavioral changes (Hammond, Mayes \& Potenza, 2014) and it is in this period that individuals look for instant gratification and thus their entire biological development is focused around instant rewards and

\footnotetext{
* Student, Department of Pharmaceutical Sciences and Technology, Institute of Chemical Technology, Mumbai, India Email: gayatri.r.iyer2018@gmail.com

${ }^{* *}$ Visiting Faculty, Institute of Chemical Technology, Mumbai, India

Email: ramaiyer2008@gmail.com
} 
instant pleasure, thus making this adolescent group very vulnerable for addictive behaviors. It may be possible to draw a similarity in the way substance abuse and internet addiction works. Drug abuse and internet addiction both restructure cognitive processes and draw the individual away from reality into a world of fantasy that seems real to him or her. Thus, compulsive use of internet, for any purpose, begins to appear more rewarding than real healthy activities, alienating the individual from his real world of social networks and relationships. The current study focuses on understanding the differences in problematic internet usage by substance users and nonusers.

\section{INTERNET ADDICTION}

There is a lack of consensus on the definition of this situation. Researchers understand the term as a difficult condition where the user interacts with the machine for such long hours, that is throws other aspects of life off-balance (Shaw \& Black, 2008). A lack of typical connection between the internet use and corresponding disorders due to over use makes it difficult for recognizing clear symptoms as those for substance abuse (Weinstein \& Lejoyeux, 2010). Unlike addictive drug or substance abuse, the internet offers benefits to the user too like ease of research, information about a variety of items, communication convenience between different parts of the world and also entertainment. Hence researchers opine that the term addictive cannot be used with the internet use since it also provides all the advantages of technological advancement (Young, 1999). Several studies have termed this behaviour differently, like Internet addiction, Pathological internet use, problematic internet use (Yellowless \& Marks, 2007).

Although internet cannot be compared with substances like alcohol or weed, there have been studies that have characterized internet addiction as similar to substance abuse (Griffiths, 1999; Shaw \& Black,2008) and obsessive-compulsive disorders (Santos et al. 2015). Different studies have looked at different sets of behaviors associated with long hours at the internet. (Table 1).

\begin{tabular}{|l|l|}
\hline Table 1: Common behaviors associated with internet overuse \\
\hline Researchers & Internet Addiction types \\
\hline Musetti et al.(2016) & $\begin{array}{l}\text { Cybersexual addiction that includes cybersex } \\
\text { and cyberporn }\end{array}$ \\
\hline Hormes, Kearns, and Timko (2014), & $\begin{array}{l}\text { Cyber relationship that includes an obsession } \\
\text { to make online relationships }\end{array}$ \\
\hline Gunuc and Keskin(2016) & Online gambling, online shopping \\
\hline & Compulsive information search \\
\hline Ng and Wiemer-Hastings (2005) & Online gaming \\
\hline
\end{tabular}

Internet addiction has been described as an uncontrolled compulsive use of the computer that leads to personal and professional distress, impaired social and occupational functioning and cognitive dysfunction (Black et al.1999; Shapira et al. 2003; Shek et al. 2015). Research studies have suggested that long hours spent at the internet has resulted in wide mood swings, adverse functioning at office or academics. Some other research studies have shown that indiscriminate use of the internet can lead to anxiety, depression, hostile tendencies attention deficit hyperactive disorder (Ko et al.2012). Inclusion of internet addiction in the American Society of Addiction Medicine has been justified by the fact that like any other substance abuse, over use of internet is accompanied by similar outcomes that affect cognitive control and decisions, a false temporary feeling of relief and peace and a momentary mood elevation (Cash, 2012).

\section{INTERNET ADDICTION AND ADOLESCENTS}

With the upsurge in technology and media, adolescents being exposed to the internet and using the same without restraint is on the rise. Reports of internet addiction among adolescents of 
many countries have been reported in various studies. Adolescent health in all respects is of paramount importance because this category goes on to become the future of any nation. Along with physical health, mental health is also equally important. Tsai and Lin (2003) in their research study on internet addiction among adolescents in Taiwan found that internet addiction was attributed to the fact that all necessary and important information used to come to these individuals via the internet. In a study on problematic internet use in Lebanon it was found that addiction was the most severe in ages in the group of 12-16 years adolescents (Hawi, 2012). Several research studies have shown the association of internet addiction with symptoms like depression and compulsive disorders (Ha et al. 2007), cyberbullying, hostility and social anxiety (Ko et al. 2014), lack of self-esteem (Yen et al. 2014), problematic alcohol abuse (Ko et al. 2008) and suicidal intentions (Kim et al. 2006). Many research studies study on internet addiction among university students showed a strong association between internet addiction and adverse psycho-social conditions in Greece (Polyxeni, 2014), Indonesia (Pratama and Widyanti, 2019) and Turkey (Boylu \& Gunay, 2019). The problems of adolescents especially engineering students become even more pronounced as these students are burdened by the rigour of their academics and confronted by their vulnerability of age.

Investigations in the topic of internet addictions have mainly been centred around understanding the level of addiction present in any population (Poli \& Agrimi, 2012; Moreno et al. 2011) of regarding the predictors of internet addiction (Ceyhan, 2008; Tsitsika et al.2009) or the consequences of internet addiction (Akin, 2012). Very few research studies have explored differences in internet addiction among substance users in the Indian context.

\section{INTERNET ADDICTION SCALES}

There have been a large number of internet addiction scales that have been used which are multidimensional (Samaha etal., 2018; Siomos et al. 2008). The scales also show a factorial complexity mainly because of the differences in the definition of the internet addiction construct itself. The IAT (Young, 1998) which is possibly the most commonly used scale itself shows a different factor structure in different studies. A Thai version of the IAT showed a three-factor model (Neelapaijit et al. 2018). A study on Italian university students showed a two-factor model of the IAT which demonstrated good psychometric properties (Servidio, 2017), whereas a study on psychometric properties of the IAT on Malaysian students yielded a six-factor structure (Xi \&Yeo, 2015). IAT is intended for adults and hence does not capture the situation faced by engineering students. Though many instruments are available, none of them has succeeded in reaching an agreement on the measurement and that is mainly due to the disagreement in the definition of internet addiction. There is no internet addiction scale that identifies with engineering students specifically and hence the motivation for the current study.

Internet is quintessential for academic and occupational functioning in society. Internet addiction is likely to become a public health issue in the near future as youngsters have access to the internet anytime, anywhere on smart phones. In this situation, a systematically developed and validated tool could assist in identifying current status, preventative intervention, and countermeasures in engineering colleges.

The current study is an attempt to develop and validate a questionnaire to measure internet addiction among engineering (IATE) students in India. The study will also explore differences in internet addition between substance users and non-users. 


\section{METHOD}

\section{Development and Validation of Internet Addiction Scale}

A preliminary questionnaire of 20 items were compiled from literature review (Babalola, 2019; Bisen \& Deshpande, 2020). Next, an expert group consisting of psychiatrist, psychologist, students identified as problematic internet users by college counsellors and counsellors themselves determined 16 preliminary items after a series of discussions. Examples of items are:

- 'I am unable to concentrate on my studies'

- 'I get lot of complaints from my family regarding my long hours on the internet'

- 'I can easily make friends online than when I am face to face with people'

Responses were recorded on a 6 point Likert scale ranging from $0=$ 'Never ' to $5=$ 'Always'

\section{Sampling}

Convenience sampling method was used where 97 participants(freshmen) were identified from four universities in Mumbai, India. The names of the participants were given by the institution counsellors who had identified these students as over-users(those who spent more than 7 hours a day on the internet). Questionnaire survey method was used and the researcher personally collected the answered questionnaires.

\section{The Instrument}

The final instrument consisted of two parts. The first part was demographic data that included gender age, residency status of whether the student is a hosteler or a day scholar, weekly number of hours of internet usage and whether the respondent owned a device with internet access. The second part consisted of 16 items, on a 6-point Likert scale, that measured aspects of internet addiction.

\section{RESULTS}

\section{Data Analysis}

SPSS 16 was used for analysis of data.

The Internet addiction questionnaire (IATE) was validated using factor analysis and validity studies (convergent and discriminant).

\section{Sample Description}

The sample consisted of 97 first year engineering students (64\% males and $36 \%$ females) whose average age was 18.5 years (standard deviation $=1.57$ years). $80 \%$ were hostelers while $20 \%$ of the students stayed in their own homes. $39 \%$ of students were hostelers while $61 \%$ were day scholars. $99 \%$ of the respondents owned a device that had internet access while only $1 \%$ did not own a device with internet access. The weekly average time spent on the internet irrespective of the purpose was 52.3 hours (standard deviation $=7.21$ hours) that roughly stands at an average of 7 hours daily.

\section{Factor Analysis}

It is common to try and combine items into common factors so that it enables the researcher to interpret factors easily and clearly based on the item loading onto the factor. The 16 items were examined for their factorability. The Kaiser-Meyer-Olkin measure of sampling adequacy was 0.820 above the commonly recommended value of 0.6 , and Bartlett's test of sphericity was significant $(\chi 2(120)=614.491, p<.01)$. The diagonals of the anti-image correlation matrix were all above 0.6 . The communalities were all above 0.3 ,confirming that each item shared some common variance with other items (Table 2). Given these overall indicators, factor analysis was deemed to be suitable with all 16 items. 
Initial Eigen values indicated that the first three factors explained $37.29 \%, 10.28 \%$, and $8.12 \%$ of the variance respectively. The three-factor solution, explained $55.71 \%$ of the variance. This was also indicated by the leveling off of eigen values on the scree plot after three factors and the inability of subsequent factors to be amenable for interpretation. There were no cross loadings observed in the final structure.The first component was labeled Preoccupation, the second component was labeled Social withdrawal and the third component was named Mood swings.

The descriptive statistics for each of the four factors has been given in Table 3. Table 2: Factor loadings and communalities based on a principal components analysis with
varimax rotation for 16 items of the Internet addiction scale, IATE $(n=97)$

\begin{tabular}{|c|c|c|c|c|}
\hline Items & Preoccupation & $\begin{array}{l}\text { Social } \\
\text { withdrawal }\end{array}$ & $\begin{array}{l}\text { Mood } \\
\text { swings }\end{array}$ & Communalities \\
\hline $\begin{array}{l}\text { I am unable to concentrate on } \\
\text { my studies }\end{array}$ & 0.706 & & & 0.588 \\
\hline $\begin{array}{l}\text { I prefer to engage in online } \\
\text { activities rather than outdoor } \\
\text { physical activities }\end{array}$ & 0.704 & & & 0.525 \\
\hline $\begin{array}{l}\text { I seem to get hooked to the } \\
\text { internet for more time than } \\
\text { what I really want to }\end{array}$ & 0.656 & & & 0.576 \\
\hline $\begin{array}{l}\text { I only think about what next to } \\
\text { surf in the internet }\end{array}$ & 0.632 & & & 0.443 \\
\hline $\begin{array}{l}\text { I like to meet people and make } \\
\text { friends online rather than in real } \\
\text { life }\end{array}$ & 0.626 & & & 0.410 \\
\hline $\begin{array}{l}\text { I spend long hours on the } \\
\text { internet without getting bored }\end{array}$ & 0.602 & & & 0.503 \\
\hline $\begin{array}{l}\text { I feel that the virtual world is lot } \\
\text { more exciting than the real } \\
\text { world }\end{array}$ & 0.525 & & & 0.537 \\
\hline $\begin{array}{l}\text { I rather be surfing the internet } \\
\text { than go out with family and } \\
\text { friends }\end{array}$ & & 0.8 & & 0.668 \\
\hline $\begin{array}{l}\text { I can easily make friends online } \\
\text { than when I am face to face with } \\
\text { people }\end{array}$ & & 0.719 & & 0.603 \\
\hline $\begin{array}{l}\text { I often lose my rest and sleep } \\
\text { due to the internet }\end{array}$ & & 0.7 & & 0.589 \\
\hline $\begin{array}{l}\text { I get lot of complaints from my } \\
\text { family regarding my long hours } \\
\text { on the internet }\end{array}$ & & 0.693 & & 0.551 \\
\hline $\begin{array}{l}\text { I try to keep away from a crowd } \\
\text { in order to check my mobile } \\
\text { phone for mails }\end{array}$ & & 0.675 & & 0.640 \\
\hline $\begin{array}{l}\text { I get tense when I cannot check } \\
\text { the internet the first thing in my } \\
\text { day }\end{array}$ & & & 0.752 & 0.568 \\
\hline $\begin{array}{l}\text { I get wild when people ask me } \\
\text { about my internet activities }\end{array}$ & & & 0.734 & 0.612 \\
\hline
\end{tabular}




\begin{tabular}{|c|c|c|}
\hline $\begin{array}{l}\text { I find solace in browsing the } \\
\text { internet when I feel sad } \\
\text { regarding my poor performance } \\
\text { in exams and grades }\end{array}$ & 0.595 & 0.537 \\
\hline $\begin{array}{l}\text { I feel very uneasy when the } \\
\text { internet fails but feel reassured } \\
\text { the minute it gets restored }\end{array}$ & 0.557 & 0.564 \\
\hline
\end{tabular}

\begin{tabular}{|l|l|l|l|l|l|}
\hline Table 3: Descriptive statistics for the Internet addiction Scale, IATE (n=97) \\
\hline & $\begin{array}{l}\text { Number of } \\
\text { Items }\end{array}$ & $\begin{array}{l}\text { Mean } \\
\text { (SD) }\end{array}$ & Skewness & Kurtosis & $\begin{array}{l}\text { Cronbach's } \\
\text { Alpha } \\
\text { Coefficient }\end{array}$ \\
\hline Preoccupation & 7 & $\begin{array}{l}12.16 \\
(6.27)\end{array}$ & 0.662 & 1.006 & 0.814 \\
\hline Social withdrawal & 5 & $\begin{array}{l}8.14 \\
(4.75)\end{array}$ & 0.697 & 0.461 & 0.824 \\
\hline Mood swings & 4 & $\begin{array}{l}6.93 \\
(3.98)\end{array}$ & 0.437 & -0.532 & 0.728 \\
\hline
\end{tabular}

\section{VALIDITY OF THE SCALE}

Convergent and Discriminant validity analyses were done for the Internet overuse scale. It can be seen that the standardized factor loading of each item is above 0.5 (Table 4), the scale composite reliability (SCR) is well above 0.7 and the average variance extracted (AVE) is also above 0.5 (Table 3). AVE should ideally be greater than or equal to 0.5 but lower values can be accepted as composite reliability is well above 0.6 (Huang et al. 2013; Fornell \& Larcker, 1981). Thus, convergent validity is established for the scale.

\begin{tabular}{|c|c|c|c|c|c|c|}
\hline Construct & Items & $\begin{array}{l}\text { Factor } \\
\text { loading }\end{array}$ & Variance & Error & SCR & AVE \\
\hline \multirow[t]{7}{*}{$\begin{array}{l}\text { Preoccupa } \\
\text { tion }\end{array}$} & $\begin{array}{l}\text { I am unable to concentrate } \\
\text { on my daily routine work }\end{array}$ & 0.706 & 0.498436 & 0.294 & 0.885 & 0.407 \\
\hline & $\begin{array}{l}\text { I prefer to engage in online } \\
\text { activities rather than } \\
\text { outdoor physical activities }\end{array}$ & 0.704 & 0.495616 & 0.296 & & \\
\hline & $\begin{array}{l}\text { I seem to get hooked to the } \\
\text { internet for more time than } \\
\text { what I really want to }\end{array}$ & 0.656 & 0.430336 & 0.344 & & \\
\hline & $\begin{array}{l}\text { I only think about what next } \\
\text { to surf in the internet }\end{array}$ & 0.632 & 0.399424 & 0.368 & & \\
\hline & $\begin{array}{l}\text { I like to meet people and } \\
\text { make friends online rather } \\
\text { than in real life }\end{array}$ & 0.626 & 0.391876 & 0.374 & & \\
\hline & $\begin{array}{l}\text { I spend long hours on the } \\
\text { internet without getting } \\
\text { bored }\end{array}$ & 0.602 & 0.362404 & 0.398 & & \\
\hline & $\begin{array}{l}\text { I feel that the virtual world is } \\
\text { lot more exciting than the } \\
\text { real world }\end{array}$ & 0.525 & 0.275625 & 0.475 & & \\
\hline
\end{tabular}




\begin{tabular}{|c|c|c|c|c|c|c|}
\hline \multirow[t]{5}{*}{$\begin{array}{l}\text { Social } \\
\text { withdrawa } \\
\text { I }\end{array}$} & $\begin{array}{l}\text { rather be surfing the } \\
\text { internet than go out with } \\
\text { family and friends }\end{array}$ & 0.8 & 0.64 & 0.2 & 0.901 & 0.516 \\
\hline & $\begin{array}{l}\text { I look for excuses to stay } \\
\text { away from parties and get } \\
\text { together }\end{array}$ & 0.719 & 0.516961 & 0.281 & & \\
\hline & $\begin{array}{l}\text { I often lose my rest and } \\
\text { sleep due to the internet }\end{array}$ & 0.7 & 0.49 & 0.3 & & \\
\hline & $\begin{array}{l}\text { I get lot of complaints from } \\
\text { friends regarding my } \\
\text { internet habits }\end{array}$ & 0.693 & 0.480249 & 0.307 & & \\
\hline & $\begin{array}{l}\text { I try to keep away from a } \\
\text { crowd in order to check my } \\
\text { mobile phone for mails }\end{array}$ & 0.675 & 0.455625 & 0.325 & & \\
\hline \multirow[t]{4}{*}{$\begin{array}{l}\text { Mood } \\
\text { swings }\end{array}$} & $\begin{array}{l}\text { I get tense when i cannot } \\
\text { check the internet the first } \\
\text { thing in my day }\end{array}$ & 0.752 & 0.565504 & 0.248 & 0.836 & 0.728 \\
\hline & $\begin{array}{l}\text { I get irritated when people } \\
\text { ask me about my internet } \\
\text { activities }\end{array}$ & 0.734 & 0.538756 & 0.266 & & \\
\hline & $\begin{array}{l}\text { I find solace in browsing the } \\
\text { internet when I feel sad }\end{array}$ & 0.595 & 0.354025 & 0.405 & & \\
\hline & $\begin{array}{l}\text { I feel very uneasy when the } \\
\text { internet fails but feel } \\
\text { reassured the minute it gets } \\
\text { restored }\end{array}$ & 0.557 & 0.310249 & 0.443 & & \\
\hline
\end{tabular}

Discriminant validity for the Scale (Table 5 ) is established as correlations between any two dimensions are lesser than their individual Cronbach alpha values (Iyer, 2017; Andaleeb \& Conway, 2006; Richey et al. 2005; Gaski \& Nevin, 1985).

\begin{tabular}{|l|l|l|l|}
\hline Table 5: Discriminant validity for Internet addiction Scale, IATE (n= 97) \\
\hline Component & Preoccupation & $\begin{array}{l}\text { Social } \\
\text { withdrawal }\end{array}$ & Mood swings \\
\hline Preoccupation & $\mathbf{0 . 8 1 4}$ & & \\
\hline Social withdrawal & $0.523^{* *}$ & $\mathbf{0 . 8 2 4}$ & \\
\hline Mood swings & $0.520^{* *}$ & $0.559^{* *}$ & $\mathbf{0 . 7 2 8}$ \\
\hline
\end{tabular}

Diagonal entries are Cronbach alpha coefficients: others are Pearson's correlation coefficient

** correlations are significant at 0.01 levels

The results of the factor analysis and the validity studies show that the Internet overuse scale is a reasonably accurate measure of aspects of Internet overuse among engineering students. The Cronbach alpha values as also the scale composite reliability values establish the reliability of the scale. The instrument as good reliability as well as validity and can be used for further research studies. Internet addiction has been predicted as one of the symptoms that will engulf the youth of today and engineering students being the technological background of any country, this instrument can be used to detect internet overuse and design timely interventions. 


\section{DIFFERENCES IN INTERNET ADDICTION AMONG SUBSTANCE USERS AND NON-USERS}

In addition to developing and validating a questionnaire to measure internet addiction among engineering students, an endeavor was made to explore differences among substance users and non-users with regards internet addiction score. An independent samples-t-test was conducted for this purpose. We could conduct the t-test since the data satisfied the criteria required for being amenable for t-test(Howell,2011). The dependent variable internet addiction, measured on a 6-point Likert scale, is an interval variable. The independent variable Substance user consists of 2 categories, 'users' and 'non-users'. There were no significant outliers (Fig 1).

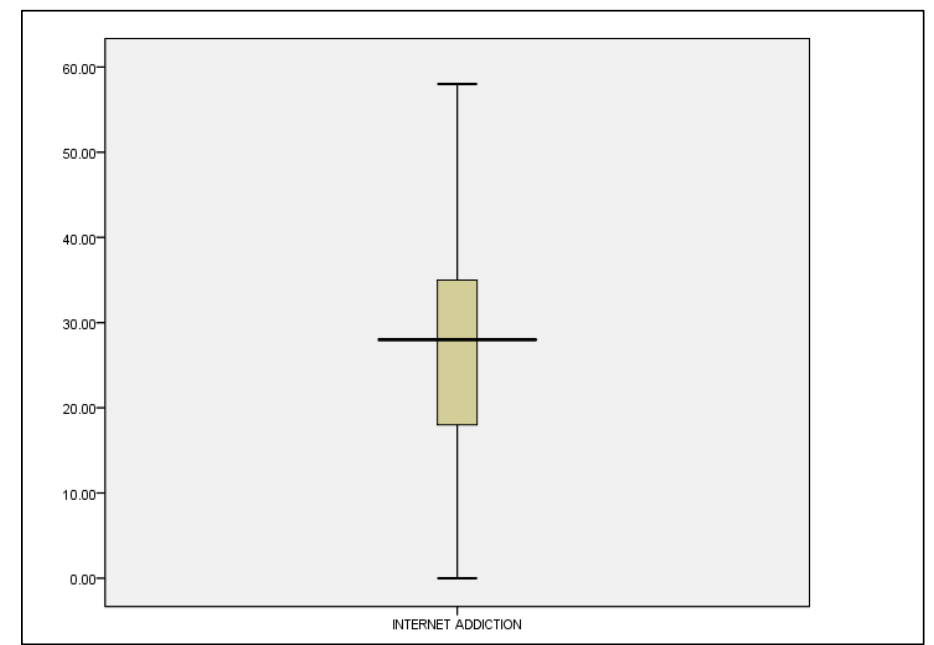

Fig 1. Box plot of Internet Addiction

Homogeneity of variances was tested using Levene's test for homogeneity of variances. Variances were assumed to be equal for the substance users vs. non users. $(F=.137, p=.712)$. . The Shapiro Wilk test was used (Guo, 2012; Zimmerman, 2003). Both the independent groups were found to be normally distributed: Substance user ( $W=.982, p=0.816)$, non -users ( $W=.986, p=0.702)$. In addition, it was found that the skewness and kurtosis values of internet addiction for both the categories of independent variable were found to be less than the thresholds of 2 and 7 respectively (lyer, 2017; Curran et al. 1996; lyer, 2017; Kim, 2013). An independent samples t test was conducted to assess the difference in internet overuse scores between substance users and non-users (Table 6).

\begin{tabular}{|l|l|l|l|l|l|}
\hline Table 6: Independent samples t-tests $(\mathbf{n}=97)$ \\
\hline Component & $\begin{array}{l}\text { Levene's test for equality of } \\
\text { variances }\end{array}$ & $\boldsymbol{F}$ & Sig & $\mathrm{t}$ & $\begin{array}{l}\text { Sig. } \\
\text { tailed) }\end{array}$ \\
\hline & 0.137 & 0.712 & -2.489 & 0.015 \\
\hline $\begin{array}{l}\text { Internet } \\
\text { overuse }\end{array}$ & & & \\
\hline
\end{tabular}

The independent samples-t-test was used to compare internet addiction scores between substance users and non-users. There was a significant difference in the scores for Substance Non users $(M=24.93, S D=12.06)$ and Users $(M=31.34, S D=12.38 ; t(95)=-2.489, p<0.05)$. The magnitude of differences in means was moderate (eta squared $=0.06$ ) (Cohen, 1988) 


\section{DISCUSSION}

There is a significant difference in internet addiction scores between substance users and substance non-users. In the current sample, $64 \%$ have admitted to be substance users while 36 $\%$ are not substance users. Substances included either illicit drugs, alcohol or cigarettes or all of them. Alcohol, smoking and illicit drug use are a problematic trio for most adolescents that is a common make up of their lifestyles and impacts their social dynamics, cognitive processes and decision making abilities, behaviour and vulnerability(Ko et al., 2008). Young(2011) has opined that people who have other substance dependencies like alcohol, illicit drugs and cigarettes are more prone to getting addicted to the internet because their compulsive behaviour apparently helps them overcome difficulties and hurdles. Yen, Yen and Ko (2010) have found that when an MRI was conducted the areas that were activated when an individual had an urge to use the internet are the same as those activated by addictive substances. So the result depicted by the ttest (Table 6) is not surprising at all.

Engineering students enter a new world when they leave home for the first time for a professional course and face a new environment. This sample has $80 \%$ of students staying in hostels away from their homes. This is a transition face that few people get adjusted to quickly while some take their own time while some never adjust. Students encounter many situations in this phase like rigour of academics, assignment submissions, project work, new friends and colleagues and a completely new environment. Many also undergo turmoil in their personal lives like romantic involvements, breakups and, failures or low scores in academics and they are mentally not attuned to accept these They face all these turmoil on their own and possibly find it difficult and too early to develop any confidant. Also, since majority of the students are hostelers, there is no external control from somebody who is close to them. Individuals spend a lot of time on the internet as a defence mechanism in order to conceal certain emotionally or physically threatening situations or to combat loneliness. The internet is a very viable and attractive ghetto for individuals to escape from real life and set up a world that is non-real.

Communication suddenly seems easier with people the student never knows, confiding one's fears and apprehensions in an unreal world. Many students also drown themselves in the internet in the quest for knowing more and more while some will drown themselves in gaming, online shopping and sometimes cyberporn. Freshmen are very vulnerable due to the complete change in their environment and hence are prone to substance use too in addition to internet overuse. It was also found that adolescents in Taiwan (with an average age of 16 years) with this combination of three abusive behaviors also exhibited problematic internet usage behaviors (Ko et al., 2008). Several studies have also shown internet addiction associated with problematic alcohol usage (Yen et al. 2009).

The current study is similar to a study conducted by Lee, Hans, Kim, and Renshaw (2013) where it was seen that substance users were at a high risk to internet addiction. Drug abuse reduces an individual's cognitive abilities alienating him or her from the real world. The internet is perceived as a safe place for such individuals to seek refuge or even heighten the pleasurable effects of abusive substance. Alcohol users experience a general high after its consumption. Alcohol is associated with the release of Dopamine that affects reasoning power and sense making which in turn results in fool hardy fun-seeking behaviors. The internet provides such users a perfect haven to satisfy their urges while remaining away from the actual reality. In a study on an association between smoking and internet addiction among Japanese adolescents, it was found that adolescents who smoked routinely or were regular smokers are more addicted to the internet than the non-smokers (Morioka et al.,2016). The results of this study support the findings of previous studies that adolescents who are substance abusers have a greater propensity to exhibit internet addictive behaviors. 
The current study suffers from various limitations. The study could not include variables like family background, parental support and faculty support, low self-esteem, attention deficit disorder and other personality traits and their impact on addiction. A convenience sampling method could make the results of the study less generalizable across populations.

\section{CONCLUSION}

We believe that this study is possibly one of the very few studies that have been conducted on substance abusers and internet addiction among engineering freshmen in the Indian context. Access limitation and blocking of certain sites that would prevent these adolescents from spending an indiscriminate amount of their time on campus on the internet might be helpful since free access to the internet on most college campuses is an incentive for students to get hooked on. Similarly service providers recognizing the harmful impact of internet over-usage can do their social part by limiting access to certain sites as per the age of the user. In addition to these physical and technological interventions, socio-psychological interventions are also a clear must. CBT has been effectively used for addictive behaviors (Lee et al. 2019). The counsellor may have a few sessions with close family members to understand the relationship dynamics and then plan family therapies.

Internet addiction is becoming a serious problem plaguing our society. Effective interventions and awareness programmes should be delivered on campus to promote the ill effects of overuse of the internet. It is also essential to counsel family members and promote the value of connection with parents, relatives, friends and a social life beyond the engineering classroom. Programmes that engage students in meditation, yoga and intense physical activities should be encouraged so that students learn to encounter face to face interactions with real humans rather than the surreal ones behind their screens. It is also essential that parents, teachers and other authorities recognize changing behaviors among students and create an environment of congeniality where the individual can share his or her feelings openly with his near and dear ones.

\section{REFERENCES}

Akın, A. (2012). The Relationships Between Internet Addiction, Subjective Vitality, and Subjective Happiness. Cyberpsychology, Behavior, and Social Networking, 15(8), 404-410. doi:10.1089/cyber.2011.0609

Samaha, A. A., Fawaz, M., Yahfoufi, N. E., Gebbawi, M., Abdallah, H., Baydoun, S. A., . . Eid, A. H. (2018). Assessing the Psychometric Properties of the Internet Addiction Test (IAT) Among Lebanese College Students. Frontiers in Public Health, 6. doi:10.3389/fpubh.2018.00365

Andaleeb, S. S., \& Conway, C. (2006). Customer satisfaction in the restaurant industry: An examination of the transaction-specific model. Journal of Services Marketing, 20(1), 3-11. doi:10.1108/08876040610646536

Bablola,O.B. (2019). Gender Differences on the Influence of Peer Relations and Behavioural Pattern of Internet Usage on Internet Addiction among Youths in Osun State, Nigeria. Gender \& Behaviour, 17(4), 14433-14441.

Beard, K. W., \& Wolf, E. M. (2001). Modification in the Proposed Diagnostic Criteria for Internet Addiction. CyberPsychology \& Behavior, 4(3), 377-383. doi:10.1089/109493101300210286

Bisen, S., \& Deshpande, Y. (2020). Prevalence, predictors, psychological correlates of internet addiction among college students in India: A comprehensive study. Anatolian Journal of Psychiatry, 21(0), 1. doi:10.5455/apd.47328

Black, D. W., Belsare, G., \& Schlosser, S. (1999). Clinical Features, Psychiatric Comorbidity, and Health-Related Quality of Life in Persons Reporting Compulsive Computer Use Behavior. The Journal of Clinical Psychiatry, 60(12), 839-844. doi:10.4088/jcp.v60n1206 
Boylu, A. A., \& Günay, G. (2019). Loneliness and Internet Addiction Among University Students. Internet and Technology Addiction, 382-398. doi:10.4018/978-1-5225-8900$6 . c h 022$

Cash, H., Rae, C. D., Steel, A. H., \& Winkler, A. (2012). Internet Addiction: A Brief Summary of Research and Practice. Current Psychiatry Reviews, 8(4), 292-298. doi:10.2174/157340012803520513

Cao, F., \& Su, L. (2007). Internet addiction among Chinese adolescents: Prevalence and psychological features. Child: Care, Health and Development, 33(3), 275-281. doi:10.1111/j.1365-2214.2006.00715.x

Ceyhan, A. A. (2008). Predictors of Problematic Internet Use on Turkish University Students. CyberPsychology \& Behavior, 11(3), 363-366. doi:10.1089/cpb.2007.0112

Chang, F., Chiu, C., Miao, N., Chen, P., Lee, C., Chiang, J., \& Pan, Y. (2015). The relationship between parental mediation and Internet addiction among adolescents, and the association with cyberbullying and depression. Comprehensive Psychiatry, 57, 21-28. doi:10.1016/j.comppsych.2014.11.013

Chou, W., Huang, M., Chang, Y., Chen, Y., Hu, H., \& Yen, C. (2017). Social skills deficits and their association with Internet addiction and activities in adolescents with attentiondeficit/hyperactivity disorder. Journal of Behavioral Addictions, 6(1), 42-50. doi:10.1556/2006.6.2017.005

Cohen J. (1988). Statistical Power Analysis for the Behavioral Sciences. New York, NY: Routledge Academic

Craparo, G., Messina, R., Severino, S., Fasciano, S., Cannella, V., Gori, A., . . Baiocco, R. (2014). The relationships between self-efficacy, internet addiction and shame. Indian Journal of Psychological Medicine, 36(3), 304. doi:10.4103/0253-7176.135386

Curran, P. J., West, S. G., \& Finch, J. F. (1996). The robustness of test statistics to nonnormality and specification error in confirmatory factor analysis. Psychological Methods, 1(1), 16-29. doi:10.1037/1082-989x.1.1.16

Fornell, C., \& Larcker, D. F. (1981). Evaluating Structural Equation Models with Unobservable Variables and Measurement Error. Journal of Marketing Research, 18(1), 39. doi:10.2307/3151312

Gaski, J. F., \& Nevin, J. R. (1985). The Differential Effects of Exercised and Unexercised Power Sources in a Marketing Channel. Journal of Marketing Research, 22(2), 130. doi:10.2307/3151359

Griffiths, M. (1999). Internet addiction: Fact or fiction? The Psychologist, 12(5), 246-250.

Günüç, S., \& Keskin, A. D. (2016). Online Shopping Addiction: Symptoms, Causes and Effects. Addicta: The Turkish Journal on Addictions, 3(3). doi:10.15805/addicta.2016.3.0104

Guo, J. (2012). Optimal sample size planning for the Wilcoxon-Mann-Whitney and van Elteren tests under cost constraints. Journal of Applied Statistics, 39(10), 2153-2164. doi:10.1080/02664763.2012.702265

Guo, J., Chen, L., Wang, X., Liu, Y., Chui, C. H., He, H., ... Tian, D. (2012). The Relationship Between Internet Addiction and Depression Among Migrant Children and Left-Behind Children in China. Cyberpsychology, Behavior, and Social Networking, 15(11), 585-590. doi:10.1089/cyber.2012.0261

Ha, Y., \& Hwang, W. J. (2014). Gender Differences in Internet Addiction Associated with Psychological Health Indicators Among Adolescents Using a National Web-based Survey. International Journal of Mental Health and Addiction, 12(5), 660-669. doi:10.1007/s11469-014-9500-7

Ha, J. H., Kim, S. Y., Bae, S. C., Bae, S., Kim, H., Sim, M., Lyoo, I. K., \& Cho, S. C. (2007). Depression and Internet addiction in adolescents. Psychopathology, 40(6), 424-430. https://doi.org/10.1159/000107426 
Hammond, C. J., Mayes, L. C., \& Potenza, M. N. (2014). Neurobiology of adolescent substance use and addictive behaviors: treatment implications. Adolescent medicine: state of the art reviews, 25(1), 15-32.

Hawi, N. S. (2012). Internet addiction among adolescents in Lebanon. Computers in Human Behavior, 28(3), 1044-1053. doi:10.1016/j.chb.2012.01.007

Hormes, J. M., Kearns, B., \& Timko, C. A. (2014). Craving Facebook? Behavioral addiction to online social networking and its association with emotion regulation deficits. Addiction, 109(12), 2079-2088. doi:10.1111/add.12713

Howell, D. C. (2017). Fundamental statistics for the behavioral sciences. Boston, MA: Cengage Learning.

Huang, C., Wang, Y., Wu, T., \& Wang, P. (2013). An Empirical Analysis of the Antecedents and Performance Consequences of Using the Moodle Platform. International Journal of Information and Education Technology, 217-221. doi:10.7763/ijiet.2013.v3.267

Jang, K. S., Hwang, S. Y., \& Choi, J. Y. (2008). Internet Addiction and Psychiatric Symptoms Among Korean Adolescents. Journal of School Health, 78(3), 165-171. doi:10.1111/j.17461561.2007.00279.x

Iyer, R. D. (2017). Developing and Validating a Questionnaire to Measure Some Factors of School Culture : A Psychometric Process. Prabandhan: Indian Journal of Management, 10(11), 7. doi:10.17010/pijom/2017/v10i11/119397

Kaur, S. (2018). Gender Differences and Relationship Between Internet Addiction and Perceived Social Self-Efficacy Among Adolescents. Indian Journal Of Health And Wellbeing, 9(1), 106-109. Retrieved from http://www.i-scholar.in/index.php/ijhw/article/view/166538

Kim, J. H., Lau, C., Cheuk, K., Kan, P., Hui, H. L., \& Griffiths, S. M. (2010). Brief report: Predictors of heavy Internet use and associations with health-promoting and health risk behaviors among Hong Kong university students. Journal of Adolescence,33(1), 215-220. doi:10.1016/j.adolescence.2009.03.012

Kim, K., Ryu, E., Chon, M., Yeun, E., Choi, S., Seo, J., \& Nam, B. (2006). Internet addiction in Korean adolescents and its relation to depression and suicidal ideation: A questionnaire survey. International Journal of Nursing Studies, 43(2), 185-192. doi:10.1016/j.ijnurstu.2005.02.005

Ko, C., Yen, J., Yen, C., Chen, C., \& Chen, C. (2012). The association between Internet addiction and psychiatric disorder: A review of the literature. European Psychiatry,27(1), 1-8. doi:10.1016/j.eurpsy.2010.04.011

Ko, C., Yen, J., Chen, C., Yeh, Y., \& Yen, C. (2009). Predictive Values of Psychiatric Symptoms for Internet Addiction in Adolescents. Archives of Pediatrics \& Adolescent Medicine, 163(10), 937. doi:10.1001/archpediatrics.2009.159

Ko, C., Liu, T., Wang, P., Chen, C., Yen, C., \& Yen, J. (2014). The exacerbation of depression, hostility, and social anxiety in the course of Internet addiction among adolescents: $\mathrm{A}$ $\begin{array}{llll}\text { prospective } \quad \text { study. Comprehensive } \quad \text { Psychiatry, 55(6), } & \text { 1377-1384. }\end{array}$ doi:10.1016/j.comppsych.2014.05.003

Ko, C., Yen, J., Yen, C., Chen, C., Weng, C., \& Chen, C. (2008). The Association between Internet Addiction and Problematic Alcohol Use in Adolescents: The Problem Behavior Model. CyberPsychology \& Behavior, 11(5), 571-576. doi:10.1089/cpb.2007.0199

Lee, H. W., Choi, J.-S., Shin, Y.-C., Lee, J.-Y., Jung, H. Y., \& Kwon, J. S. (2012). Impulsivity in Internet Addiction: A Comparison with Pathological Gambling. Cyberpsychology, Behavior, and Social Networking, 15(7), 373-377. doi:10.1089/cyber.2012.0063

Lee, S., Kim, M. S., \& Lee, H. K. (2019). Prevention Strategies and Interventions for Internet Use Disorders Due to Addictive Behaviors Based on an Integrative Conceptual Model. Current Addiction Reports, 6(3), 303-312. doi:10.1007/s40429-019-00265-z 
Lee, Y. S., Han, D. H., Kim, S. M., \& Renshaw, P. F. (2013). Substance abuse precedes Internet addiction. Addictive behaviors, 38(4), 2022-2025. https://doi.org/10.1016/j.addbeh.2012.12.024

Lu, X., \& Yeo, K. J. (2015). Psychometric properties of the Internet Addiction Test in a sample of Malaysian undergraduate students. Psicología Educativa, 21(1), 17-25. doi:10.1016/j.pse.2015.03.001

Mangoulia, P. (2014). Internet Addiction and Psychopathological Symptoms in Greek University Students. Journal of Addictive Behaviors Therapy \& Rehabilitation,03(03). doi:10.4172/23249005.1000125

Moreno, M. A. (2011). Problematic Internet Use Among US Youth. Archives of Pediatrics \& Adolescent Medicine, 165(9), 797. doi:10.1001/archpediatrics.2011.58

Morioka, H., Itani, O., Osaki, Y., Higuchi, S., Jike, M., Kaneita, Y., . . O Ohida, T. (2016). Association Between Smoking and Problematic Internet Use Among Japanese Adolescents: Large-Scale Nationwide Epidemiological Study. Cyberpsychology, Behavior, and Social Networking, 19(9), 557-561. doi:10.1089/cyber.2016.0182

Musetti, A., Cattivelli, R., Giacobbi, M., Zuglian, P., Ceccarini, M., Capelli, F., . . Castelnuovo, G. (2016). Challenges in Internet Addiction Disorder: Is a Diagnosis Feasible or Not? Frontiers in Psychology, 7. doi:10.3389/fpsyg.2016.00842

Naseri, L., Mohamadi, J., Sayehmiri, K., \& Azizpoor, Y. (2015). Perceived Social Support, SelfEsteem, and Internet Addiction Among Students of Al-Zahra University, Tehran, Iran. Iranian Journal of Psychiatry and Behavioral Sciences, 9(3). doi:10.17795/ijpbs-421

Neelapaijit, A., Pinyopornpanish, M., Simcharoen, S., Kuntawong, P., Wongpakaran, N., \& Wongpakaran, T. (2018). Psychometric properties of a Thai version internet addiction test. BMC Research Notes, 11(1). doi:10.1186/s13104-018-3187-y

$\mathrm{Ng}$, B. D., \& Wiemer-Hastings, P. (2005). Addiction to the internet and online gaming. Cyberpsychology \& behavior : the impact of the Internet, multimedia and virtual reality on behavior and society, 8(2), 110-113. https://doi.org/10.1089/cpb.2005.8.110

Poli, R., \& Agrimi, E. (2011). Internet addiction disorder: Prevalence in an Italian student population. Nordic Journal of Psychiatry, 66(1), 55-59. doi:10.3109/08039488.2011.605169

Pratama, G. B., \& Widyanti, A. (2019). Internet Addiction among Indonesia University Students: Musculoskeletal Symptoms, Physical and Psychosocial Behavior Problems. IOP Conference Series: Materials Science and Engineering, 528, 012015. doi:10.1088/1757$899 x / 528 / 1 / 012015$

Richardson, K. (2003). Health risks on the internet: Establishing credibility on line. Health, Risk \& Society, 5(2), 171-184. doi:10.1080/1369857031000123948

Richey, G.R., Genchev, S. E., \& Daugherty, P. J. (2005). The role of resource commitment and innovation in reverse logistics performance. International Journal of Physical Distribution \& Logistics Management, 35(4), 233-257.

Santos, V., Nardi, A., \& King, A. (2015). Treatment of Internet Addiction in Patient with Panic Disorder and Obsessive Compulsive Disorder: A Case Report. CNS \& Neurological Disorders Drug Targets, 14(3), 341-344. doi:10.2174/1871527314666150225123532

Servidio, R. (2017). Assessing the psychometric properties of the Internet Addiction Test: A study on a sample of Italian university students. Computers in Human Behavior, 68, 17-29. doi:10.1016/j.chb.2016.11.019

Shapira, N. A., Lessig, M. C., Goldsmith, T. D., Szabo, S. T., Lazoritz, M., Gold, M. S., \& Stein, D. J. (2003). Problematic internet use: Proposed classification and diagnostic criteria. Depression and Anxiety, 17(4), 207-216. doi:10.1002/da.10094

Shaw, M., \& Black, D. W. (2008). Internet addiction: definition, assessment, epidemiology and clinical management. CNS drugs, 22(5), 353-365. https://doi.org/10.2165/00023210200822050-00001 
Shek, D. T., \& Yu, L. (2016). Adolescent Internet Addiction in Hong Kong: Prevalence, Change, and Correlates. Journal of pediatric and adolescent gynecology, 29(1 Suppl), S22-S30. https://doi.org/10.1016/j.jpag.2015.10.005

Siomos, K. E., Dafouli, E. D., Braimiotis, D. A., Mouzas, O. D., \& Angelopoulos, N. V. (2008). Internet addiction among Greek adolescent students. Cyberpsychology \& behavior : the impact of the Internet, multimedia and virtual reality on behavior and society, 11(6), 653-657. https://doi.org/10.1089/cpb.2008.0088

Tsai, C. C., \& Lin, S. S. (2003). Internet addiction of adolescents in Taiwan: an interview study. Cyberpsychology \& behavior : the impact of the Internet, multimedia and virtual reality on behavior and society, 6(6), 649-652. https://doi.org/10.1089/109493103322725432

Tsitsika, A., Critselis, E., Kormas, G., Filippopoulou, A., Tounissidou, D., Freskou, A., Spiliopoulou, T., Louizou, A., Konstantoulaki, E., \& Kafetzis, D. (2009). Internet use and misuse: a multivariate regression analysis of the predictive factors of internet use among Greek adolescents. European journal of pediatrics, 168(6), 655-665. https://doi.org/10.1007/s00431-008-0811-1

Weinstein, A., \& Lejoyeux, M. (2010). Internet addiction or excessive internet use. The American journal of drug and alcohol abuse, 36(5), 277-283. https://doi.org/10.3109/00952990.2010.491880

Yen, J. Y., Ko, C. H., Yen, C. F., Chen, C. S., \& Chen, C. C. (2009). The association between harmful alcohol use and Internet addiction among college students: comparison of personality. Psychiatry and clinical neurosciences, 63(2), 218-224. https://doi.org/10.1111/j.1440-1819.2009.01943.x

Yen, C. F., Chou, W. J., Liu, T. L., Yang, P., \& Hu, H. F. (2014). The association of Internet addiction symptoms with anxiety, depression and self-esteem among adolescents with attentiondeficit/hyperactivity disorder. Comprehensive psychiatry, 55(7), 1601-1608. https://doi.org/10.1016/j.comppsych.2014.05.025

Yen, J. Y., Ko, C. H., Yen, C. F., Chen, C. S., \& Chen, C. C. (2009). The association between harmful alcohol use and Internet addiction among college students: comparison of personality. Psychiatry and clinical neurosciences, 63(2), 218-224. https://doi.org/10.1111/j.1440-1819.2009.01943.x

Yen, J.-Y., Ko, C.-H., Yen, C.-F., Wu, H.-Y., \& Yang, M.-J. (2007). The Comorbid Psychiatric Symptoms of Internet Addiction: Attention Deficit and Hyperactivity Disorder (ADHD), Depression, Social Phobia, and Hostility. Journal of Adolescent Health, 41(1), 9398. doi:10.1016/j.jadohealth.2007.02.002

Young, K.S. (1999). Internet addiction: symptoms, evaluation, and treatment. In: Vande Creek, L., Jackson, T. (eds.). Innovations in clinical practice: a source book (Vol. 17). Sarasota, FL: Professional Resource Press, pp. 19-31.

Young, K.(1999). Internet addiction: Evaluation and treatment. Student British Medical Journal, 7, 351-352.

Young, K. S. (1998). Internet Addiction: The Emergence of a New Clinical Disorder. Cyber Psychology \& Behavior, 1 (3), 237-244.https://doi.org/10.1089/cpb.1998.1.237

Young, K.(1998a). Caught in the net. New York: John Wiley.

Young, K. S. (2011). CBT-IA: The First Treatment Model for Internet Addiction. Journal of Cognitive Psychotherapy, 25(4), 304-312. doi:10.1891/0889-8391.25.4.304

Zimmerman, D. W. (2003). A Warning About the Large-Sample Wilcoxon-Mann-Whitney Test. Understanding Statistics, 2(4), 267-280. doi:10.1207/s15328031us0204_03 